\author{
Michał Jerzy Dębowski \\ ORCID: 0000-0002-8685-9750 \\ Uniwersytet Warszawski \\ https://doi.org/10.19195/1733-5779.37.2
}

\title{
Wykładnia językowa typizacji narażenia na zarażenie
}

\author{
JEL Classification: K14
}

Słowa kluczowe: narażenie na zarażenie, wykładnia językowa, znamiona czynu zabronionego

Keywords: exposure to contagion, linguistic interpretation, statutory features of crime

\begin{abstract}
Abstrakt: Narażenie na zarażenie wirusem HIV, chorobą weneryczną lub chorobą zakaźną, ciężką nieuleczalną lub realnie zagrażającą życiu stanowią czyny zabronione określone w art. 161 k.k. Wykładnia językowa znamion tych czynów jest przedmiotem nieporozumień w literaturze. Autorzy zdają się posługiwać jednocześnie trzema dyrektywami wykładni językowej: dyrektywą języka potocznego, języka prawnego i języka specjalistycznego. Wybór każdej z nich może mieć wpływ na pole kryminalizacji. Nie ma powodu, by czerpać znaczenie słów z przepisów o zapobieganiu i zwalczaniu chorób zakaźnych. Terminy omówione w artykule zostały w kodeksie użyte w sposób niezgodny z zasadami języka medycznego. Dlatego też znaczenie zwrotów użytych w ustawowym opisie znamion powinno być ustalane na podstawie dyrektywy języka potocznego.
\end{abstract}

\section{Linguistic interpretation of the typifying exposure to contagion}

Abstract: Exposure to HIV, venereal disease, or serious incurable or life-threatening disease contagion is a prohibited act as defined in article 161 of the Criminal Code. The linguistic interpretation of these acts' features has been subject to misunderstandings in literature. Authors seem to use three linguistic interpretation directives at the same time: the "common language", the "legal language", and the "specialised language" directives. Choosing any of these can influence the field of criminalisation. There is no reason to draw the meaning of words from regulations on preventing and combating infectious diseases. The discussed terms have been used in a way that is incompatible with the rules of medical language. Therefore, the meaning of the phrases used in the statutory description of the features should be determined based on the "common language" directive.

\section{Wprowadzenie}

W polskim porządku prawnym umyślne narażenie na zarażenie kryminalizuje art. 161 ustawy z dnia 6 czerwca 1997 roku — Kodeks karny (k.k.) ${ }^{1}$. W odróżnie-

1 Tekst jedn. Dz.U. z 2020 r. poz. 1444. 
niu od obecnego k.k., poprzednie polskie kodyfikacje karne - z $1932^{2}$ i z 1969 roku $^{3}$ - kryminalizację narażenia na zarażenie ograniczały do chorób wenerycznych. Artykuł 245 kodeksu z 1932 roku brzmiał:

$\S 1$ Kto, będąc dotknięty chorobą weneryczną, naraża inną osobę na zarażenie tą chorobą, podlega karze więzienia do lat 3 lub aresztu do lat 3.

$\S 2$. Jeżeli sprawcą jest małżonek pokrzywdzonego, ściganie następuje na wniosek pokrzywdzonego.

Wyjąwszy systemową rezygnację z kary aresztu, jedyną modyfikacją wprowadzoną art. 162 kodeksu z 1969 roku było zastąpienie słowa „małżonek” zwrotem „osoba pozostającą we wspólnym pożyciu” w klauzuli uzależniającej ściganie od wniosku pokrzywdzonego.

Do lat dziewięćdziesiątych XX wieku doniosłość chorób tradycyjnie zwanych wenerycznymi zmalała ${ }^{4}$. Globalnym problemem stała się pandemia AIDS $^{5}$. Obie tendencje znalazły odzwierciedlenie w brzmieniu obecnej typizacji przestępstwa narażenia na zarażenie ${ }^{6}$. Pole kryminalizacji uległo rozszerzeniu. W art. 161 k.k. wymieniono liczne, nie zawsze czytelne kategorie schorzeń. Jedynej nowelizacji art. 161 k.k. dokonano art. 13 pkt 1 ustawy z dnia 31 marca 2020 roku o zmianie ustawy o szczególnych rozwiązaniach związanych z zapobieganiem, przeciwdziałaniem i zwalczaniem COVID-19, innych chorób zakaźnych oraz wywołanych nimi sytuacji kryzysowych oraz niektórych innych ustaw ${ }^{7}$. Zwiększyły się sankcje. Dodano typ kwalifikowany — narażenie na zarażenie wielu osób. Znamiona dotychczasowych typów się nie zmieniły ${ }^{8}$. Aktualnie art. 161 k.k. brzmi:

2 Dz.U. z 1932 r. Nr 60, poz. 571; Dz.U. z 1949 r. Nr 55, poz. 437; Dz.U. z 1950 r. Nr 6, poz. 46; Dz.U. z 1951 r. Nr 58, poz. 399; Dz.U. z 1955 r. Nr 15, poz. 83; Dz.U. z 1956 r. Nr 12, poz. 61; Dz.U. z 1958 r. Nr 34, poz. 152; Dz.U. z 1959 r. Nr 36, poz. 226; Dz.U. z 1960 r. Nr 51, poz. 299.

3 Dz.U. z 1969 r. Nr 13, poz. 94; Dz.U. z 1974 r. Nr 27, poz. 157; Dz.U. z 1979 r. Nr 15, poz. 97; Dz.U. z 1982 r. Nr 16, poz. 125; Dz.U. z 1982 r. Nr 40, poz. 271; i Nr 41, poz. 273; Dz.U. z 1983 r. $\mathrm{Nr}$ 6, poz. 35, i Nr 44, poz. 203; Dz.U. z 1985 r. Nr 4, poz. 15, i Nr 23, poz. 100; Dz.U. z 1987 r. Nr 14, poz. 83; Dz.U. z 1988 r. Nr 20, poz. 135; Dz.U. z 1989 r. Nr 29, poz. 154, i Nr 34, poz. 180; Dz.U. z 1990 r. Nr 14, poz. 84, i Nr 72, poz. 422; Dz.U. z 1992 r. Nr 24, poz. 101; Dz.U. z 1993 r. Nr 17, poz. 78; Dz.U. z 1994 r. Nr 126, poz. 615; Dz.U. z 1995 r. Nr 95, poz. 475; Dz.U. z 1996 r. Nr 139, poz. 646, i Nr 139, poz. 646; Dz.U. z 1997 r. Nr 6, poz. 31, i Nr 28, poz. 152.

${ }^{4}$ H. Karge, P. Palka, Przestępstwo narażenia na zakażenie choroba zakaźna (art. 161 \& 2 k.k.) — przeglad problemów, „Studia Prawnoustrojowe” 2018, nr 39, s. 71-72.

5 K. Banasik, Przestępstwo narażenia na zarażenie wirusem HIV (art. 161 § 1 KK), „Prokuratura i Prawo" 2009, nr 6, s. 53-54.

${ }^{6}$ R. Kokot, Art. 161. [Narażenie na zarażenie], [w:] Kodeks karny. Komentarz, red. R.A. Stefański, Warszawa 2020, Legalis, teza 2; M. Derlatka, Zasadność kryminalizacji narażenia na zarażenie wirusem HIV, „Palestra” 2013, z. 7-8, s. 164.

7 Dz.U. z 2020 r. poz. 568, poz. 695, poz. 1086, poz. 1262, poz. 1478, poz. 1747.

8 Zob. uwagi komentatorów do zmian: M. Budyn-Kulik, Art. 161. Narażenie człowieka na zarażenie, [w:] M. Budyn-Kulik et al., Kodeks karny. Komentarz aktualizowany, Warszawa 2020, LEX, teza 10; J. Karnat, Art. 161. [Narażenie na zarażenie], [w:] M. Banaś-Grabek et al., Kodeks karny. Część szczególna. Art. 148-251. Komentarz, Warszawa 2020, Legalis, tezy 10 i 16; R. Kokot, 
$\S 1$. Kto, wiedząc, że jest zarażony wirusem HIV, naraża bezpośrednio inną osobę na takie zarażenie, podlega karze pozbawienia wolności od 6 miesięcy do lat 8 .

$\S 2$. Kto, wiedząc, że jest dotknięty chorobą weneryczną lub zakaźną, ciężką chorobą nieuleczalną lub realnie zagrażającą życiu, naraża bezpośrednio inną osobę na zarażenie taką chorobą, podlega karze pozbawienia wolności od 3 miesięcy do lat 5 .

$\S 3$. Jeżeli sprawca czynu określonego w $§ 2$ naraża na zarażenie wiele osób, podlega karze pozbawienia wolności od roku do lat 10.

$\S 4$. Ściganie przestępstwa określonego w $\S 1$ i 2 następuje na wniosek pokrzywdzonego.

Nowelizacja przysporzyła problemów interpretacyjnych. Jednakże art. 161 k.k. budził kontrowersje znacznie wcześniej ${ }^{9}$. Ich wyczerpujące omówienie przekracza ramy niniejszego artykułu. Opracowanie to stanowi próbę udzielenia odpowiedzi na pytanie o to, czy wykładnia językowa znamion typów czynów zabronionych z art. 161 k.k. powinna być dokonywana na podstawie tak zwanej dyrektywy języka potocznego (ogólnego) czy dyrektywy języka prawnego, czy też tak zwanej dyrektywy języka specjalistycznego, w tym wypadku medycznego.

Wykładnia językowa jest metodą wykładni o podstawowej randze. Opiera się na semiotyce. Przyznaje się jej chronologiczne, a zarazem hierarchiczne pierwszeństwo przed innymi metodami ${ }^{10}$. Oznacza to, że interpretator powinien rozpocząć wykładnię od posłużenia się językowymi dyrektywami wykładni, a w razie rozbieżności między rezultatami użycia metody językowej i innych metod, za wiążące winien przyjąć wyniki tej pierwszej, chyba że burzyłoby to podstawowe założenia aksjologiczne o prawodawcy ${ }^{11}$. W prawie karnym metoda wykładni językowej ma szczególne znaczenie ${ }^{12}$. Dyrektywa ścisłej (restrykcyjnej) wykładni przepisów karnych zabrania wykładni rozszerzającej na niekorzyść sprawcy ${ }^{13}$.

Wśród językowych ujednoznaczniających ${ }^{14}$ dyrektyw wykładni podstawową rolę odgrywa dyrektywa języka potocznego (ogólnego). Nakazuje zwrotom w tekście prawnym nadawać przede wszystkim ich znaczenie w języku potocznym. Odstępstwo od tej zasady jest dopuszczalne, gdy określony sens słów narzuca de-

op. cit., Legalis, tezy 4 i 56; G. Kamieński, Odpowiedzialność cywilna i karna za zarażenie koronawirusem, Warszawa 2020, LEX, teza 2; K. Piwowarska, T. Piwowarski, Metodyka postepowania w sprawach z zakresu prawa pracy na podstawie Regulacji COVID-19, Warszawa 2020, Legalis, cz. 1, rozdz. 4, pkt 5. Odpowiedzialność na podstawie KK zwiazana z nieprzestrzeganiem przepisów dotyczacych przeciwdziałania epidemii COVID-19; N. Krej, COVID-19. Ustawy antykryzysowe. Zbiór przepisów z omówieniem, Warszawa 2020, Legalis, rozdz. 2, pkt 3.5. Kodeks karny.

9 R. Kubiak, Odpowiedzialność karna za narażenie na zakażenie wirusem SARS-CoV-2, „Palestra” 2020, nr 6, s. 133.

10 T. Chauvin, T. Stawecki, P. Winczorek, Wstęp do prawoznawstwa, Warszawa 2016, s. 253.

11 M. Zieliński, Wyktadnia prawa. Zasady - reguty — wskazówki, Warszawa 2017, s. 210-212.

12 J. Wyrembak, Zasadnicza wyktadnia znamion przestęstw. Pozycja metody językowej oraz rezultatów jej użycia, Warszawa 2009, LEX, cz. 1, rozdz. 4, pkt 3. Pozycja metody językowej w zakresie wyktadni przepisów prawa karnego materialnego (stanowisko doktryny prawa karnego). Ranga znaczeń tekstów prawnokarnych ustalanych na podstawie metody językowej.

13 V. Konarska-Wrzosek, A. Marek, Prawo karne, Warszawa 2019, s. 72, 74.

14 Zob. Z. Ziembiński, Logika praktyczna, Warszawa 2012, s. 238. 
finicja legalna albo istnieją inne podstawy ku temu, by przyjąć znaczenie odmienne niż w języku potocznym ${ }^{15}$. Język potoczny, za pomocą którego prawodawca zapisuje normy, to metajęzyk względem języka literackiego ${ }^{16}$. Zasób słów w tym rejestrze jest bogatszy, a denotacje nazw są zwykle szersze niż w codziennej mowie. Praktyczną implikacją wyboru literackiej odmiany języka jest możliwość czerpania znaczeń ze słowników języka polskiego przy wykładni przepisów ${ }^{17}$.

Przed dyrektywą języka potocznego interpretator powinien posłużyć się tak zwaną dyrektywą języka prawnego ${ }^{18}$. Przypisuje ona zwrotom użytym przez prawodawcę takie znaczenie, jakie on sam autonomicznie dla nich ustalił. Służą do tego definicje legalne. Są to zwykle definicje projektujące i zarazem regulujące ${ }^{19}$. Mają metanormatywny charakter ${ }^{20}$. Jako normy, wiążą interpretatora. Ważna reguła konstruowania tekstu prawnego - a zarazem wskazówka interpretacyjna ${ }^{21}$ — została skodyfikowana w $\S 9$ załącznika do rozporządzenia Prezesa Rady Ministrów z dnia 20 czerwca 2002 roku w sprawie „Zasad techniki prawodawczej”22 (ZTP). Zgodnie z nią wyrażeniom zdefiniowanym w ustawie podstawowej dla danej dziedziny spraw, w szczególności w ustawie określanej jako „kodeks” lub „prawo”, należy przypisywać znaczenie ustalone w tejże ustawie.

Dyrektywa języka prawnego ma także pierwszeństwo przed tak zwaną dyrektywą języka specjalistycznego ${ }^{23}$. Ta ostatnia każe poszukiwać znaczeń w specjalistycznych językach danej grupy zawodowej czy dziedziny wiedzy (profesjolektach) ${ }^{24}$. Tylko $z$ uzasadnionych powodów reguła ta może przełamywać znaczenie ustalone przez prawodawcę ${ }^{25}$. Zdaniem Krzysztofa J. Kalety i Artura Kotowskiego znaczenie przyjęte $\mathrm{w}$ fachowej terminologii przeważa nad sensem wynikającym z leksyki języka ogólnego ${ }^{26}$. Z drugiej strony, według $\S 8$ ust. 2 pkt 1 ZTP w ustawie, należy unikać posługiwania się określeniami specjalistycznymi, o ile ich użycie nie jest powodowane zapewnieniem należytej precyzji tekstu. Rozstrzygnięcie kolizji dyrektywy języka potocznego z dyrektywą języka specjalistycznego będzie więc za każdym razem uzależnione od kontekstu.

15 S. Lewandowski et al., Logika dla prawników, Warszawa 2013, s. 265; Z. Ziembiński, op. cit., s. 239.

16 K.J. Kaleta, A. Kotowski, Podstawy prawoznawstwa, Warszawa 2016, s. 250.

17 Ibidem, s. 250-251.

18 Ibidem, s. 251.

19 S. Lewandowski et al., op. cit., s. 64, 65, 73; Z. Ziembiński, op. cit., s. 232.

20 S. Lewandowski et al., op. cit., s. 73.

${ }^{21}$ M. Zieliński, op. cit., s. 58 i 280. Autor wyjaśnia, że prawidła redakcji teksów prawnych, w tym zwłaszcza ZTP, stanowią odbicie dyrektyw wykładni.

22 Tekst jedn. Dz.U. z 2016 r. poz. 283.

23 K.J. Kaleta, A. Kotowski, op. cit., s. 251.

24 T. Chauvin, T. Stawecki, P. Winczorek, op. cit., s. 253.

25 K.J. Kaleta, A. Kotowski, op. cit., s. 252.

26 Ibidem. 
W piśmiennictwie poświęconym wykładni art. 161 k.k. posłużono się wszystkimi trzema dyrektywami. Aplikując dyrektywę języka prawnego, autorzy powołują się na definicje spisane w art. 2 ustawy z dnia 5 grudnia 2008 roku o zapobieganiu oraz zwalczaniu chorób zakaźnych u ludzi ${ }^{27}$ (U.z.z.z.). Twierdzą, że art. 161 k.k. pośrednio odwołuje się do zawartego tam słowniczka ustawowego ${ }^{28}$. Przede wszystkim przytacza się definicję pojęcia „choroba zakaźna” występującego w art. $161 \S 2$ k.k. ${ }^{29}$ Zgodnie z art. 2 pkt 3 U.z.z.z. chorobą zakaźną jest choroba wywołana przez biologiczny czynnik chorobotwórczy. Reszta przywoływanych definicji legalnych dotyczy pojęć nieobecnych w art. 161 k.k. Wskazuje się na art. 2 pkt 4 U.z.z.z. objaśniający określenie „choroba szczególnie niebezpieczna i wysoce zakaźna" ${ }^{30}$. Uczeni często wskazują też definicję „zakażenia” z art. 2 pkt 32 U.z.z.z. Zgodnie z nim jest to wniknięcie do organizmu i rozwój w nim biologicznego czynnika chorobotwórczego ${ }^{31}$. Spotyka się też odwołania do definicji pojęć „nosiciel”, „podejrzany o chorobę zakaźną” i „podejrzany o zakażenie”32 odpowiednio z art. 2 pkt 17, 20 i 21 U.z.z.z. Niekiedy uczeni równocześnie odwołują się do specjalistycznych sensów tych nazw, czerpiąc z terminologii medycznej ${ }^{33}$. Stwierdzenie, czy autor odwołuje się do języka medycyny, czy do języka potocznego, nie zawsze jest możliwe ${ }^{34}$. Dyrektywą języka potocznego posługują się wszyscy autorzy w zakresie, w jakim nie odwołują się do dwóch wcześniejszych reguł.

Różnorodność wykorzystywanych metod wykładni sprawia, że zwroty z art. 161 k.k. nie mają utrwalonych w doktrynie znaczeń, wymuszających swe zastosowanie ${ }^{35}$. Źródło nieporozumień tkwi w przemilczaniu kwestii doboru odpo-

27 Tekst jedn. Dz.U. z 2020 r. poz. 1845.

28 R. Kokot, op. cit., Legalis, teza 20.

29 Zob. R. Kokot, op. cit., Legalis, teza 14; H. Karge, P. Palka, op. cit., s. 69; M. Budyn-Kulik, op. cit., LEX, teza 4; V. Konarska-Wrzosek, Art. 161 Narażenie na zarażenie, [w:] Kodeks karny. Komentarz, red. V. Konarska-Wrzosek, Warszawa 2018, LEX, teza 4; A. Marek, Kodeks karny. Komentarz, komentarz do art. 161, Warszawa 2010, LEX, teza 2; B. Michalski, Szczególne wypadki odpowiedzialności karnej związane z narażeniem człowieka na bezpośrednie niebezpieczeństwo utraty życia albo ciężkiego uszczerbku na zdrowiu, [w:] System Prawa Karnego, t. 10. Przestęstwa przeciwko dobrom indywidualnym, red. J. Warylewski, Warszawa 2016, s. 321; M. Bartnik, Odpowiedzialność karna za narażenie na zarażenie HIV i AIDS, „Studia Prawnicze KUL”2017, nr 3 (71), s. 9; R. Kubiak, op. cit., s. 119.

${ }^{30}$ Zob. R. Kokot, op. cit., Legalis, teza 14; M. Budyn-Kulik, op. cit., LEX, teza 4; B. Michalski, op. cit., s. 321.

31 H. Karge, P. Palka, op. cit., s. 69; R. Kokot, op. cit., Legalis, teza 20; B. Michalski, op. cit., s. 326; M. Bartnik, op. cit., s. 9.

32 M. Bartnik, op. cit., s. 9; R. Kubiak, op. cit., s. 122; B. Michalski, op. cit., s. 326; R. Kokot, op. cit., Legalis, teza 40.

33 H. Karge, P. Palka, op. cit., s. 68; R. Kokot, op. cit., Legalis, tezy 19-20.

34 Zob. R. Kubiak, op. cit., s. 121-122 i dokonane tam rozróżnienie pojęć „zarażenia” i ,zakażenia".

35 J. Wyrembak, op. cit., LEX, cz. 1, rozdz. 3, pkt 2. Istota metody językowej. 
wiednich dyrektyw wykładni językowej. Trzy wymienione dyrektywy wykładni — jako dyrektywy ujednoznaczniające i zarazem reguły egzegezy — pełnią taką samą funkcję ${ }^{36}$. Wskazują źródła znaczeń zwrotów użytych w tekście prawnym. Wybór jednej z nich może mieć wpływ na zakres kryminalizacji.

\section{Weryfikacja możliwości zastosowania dyrektywy języka prawnego}

Wskazanie przesłanek stosowania dyrektywy języka prawnego prima facie nie nastręcza kłopotów. Nie budzi wątpliwości obowiązek posługiwania się definicjami legalnymi w obrębie jednego aktu prawnego ${ }^{37}$. Kłopotów przysparza zagadnienie tak zwanego zasięgu zewnętrznego definicji legalnych ${ }^{38}$. W tym zakresie wskazówkę zawiera § 148 ZTP:

Jeżeli w ustawie zachodzi wyjątkowo potrzeba odstąpienia od znaczenia danego określenia ustalonego w ustawie określanej jako „kodeks” lub „prawo” lub innej ustawie podstawowej dla danej dziedziny spraw, wyraźnie podaje się inne znaczenie tego określenia i zakres jego odniesienia [... $]^{39}$.

Kodeks karny nie podaje definicji legalnej żadnego zwrotu użytego w art. 161 k.k. Jedynym zewnętrznym aktem prawnym, który mógłby ustalać wiążące znaczenie pojęć występujących w tej jednostce redakcyjnej jest akt nieopatrzony tytułem „kodeks” ani „prawo”. Jest nim U.z.z.z. Definicje legalne licznie występujące w U.z.z.z. nie powinny jednak znaleźć zastosowania w procesie wykładni art. 161 k.k. z następujących względów.

Po pierwsze, jedynymi zwrotami występującymi w art. 161 k.k. i zarazem zdefiniowanymi w U.z.z.z. są „choroba zakaźna” i „HIV”. W obu przypadkach są to właściwie definicje sprawozdawcze ${ }^{40}$ terminów faktycznych. Nie nadano im znaczeń odbiegających od występujących powszechnie ${ }^{41}$, co budzi wątpliwości z punktu widzenia $§ 146$ ZTP. Odwoływanie się w toku wykładni do definicji, które nie modyfikują potocznego znaczenia wyrażeń jest zbędne.

Po drugie, wątpliwości budzi pozycja U.z.z.z. Z perspektywy systemu prawa ma ona podstawowe znaczenie dla regulacji profilaktyki chorób zakaźnych ${ }^{42}$. Za to z perspektywy samej dziedziny, epidemiologii, odpowiedź nie jest oczy-

36 Z. Ziembiński, op. cit., s. 238-239; K.J. Kaleta, A. Kotowski, op. cit., s. 249-252.

37 S. Lewandowski et al., op. cit., s. 72-73.

38 Zob. M. Zieliński, op. cit., s. 188.

39 Ibidem, s. 72-73. Wysłowiona tam wskazówka nawiązuje do ZTP.

${ }^{40} \mathrm{~W}$ art. 2 pkt 3 i art. 41 ust. 4 U.z.z.z. Zob. S. Lewandowski et al., op. cit., s. 63-64 i podział definicji na sprawozdawcze i projektujące.

${ }^{41}$ Dalej zostanie ukazane rozumienie w języku potocznym pojęcia choroby zakaźnej jako choroby wywołanej przez drobnoustroje chorobotwórcze. Artykuł 2 pkt 3 zamiast słów „drobnoustroje chorobotwórcze” używa określenia „biologiczny czynnik chorobotwórczy”. Co ciekawe, wynikająca z art. 2 pkt 3 w zw. z art. 2 pkt 2 U.z.z.z. definicja choroby zakaźnej nie współgra z terminologią medyczną. Wyróżnia się w niej choroby zakaźne i choroby pasożytnicze.

${ }^{42}$ M. Bartnik, op. cit., s. 8. 
wista. U.z.z.z. nie reguluje zagadnień związanych z dyscypliną prawniczą, lecz medyczną. Tymczasem definicje legalne traktuje się niekiedy jako wzmocnienie argumentu, wypływającego z akceptacji pewnych znaczeń w języku prawnym ${ }^{43}$. W podręcznikowych omówieniach dyrektywy języka prawnego podaje się przykłady terminów prawnych ${ }^{44}$ (na przykład ,,powód”, „wstępny”) ${ }^{45}$. Nazwy „,choroba zakaźna” i „HIV” nie wykazują ścisłych więzi z językiem prawnym.

O braku podstawowego znaczenia U.z.z.z. w systemie prawa świadczy też brak synchronizacji nowelizacji U.z.z.z. i jej poprzedniczek ze zmianami w przepisach innych dziedzin. Modyfikacje towarzyszące wejściu w życie U.z.z.z. ograniczały się do wynikających z art. 55-63 U.z.z.z. dostosowań w prawie medycznym i pojedynczych korekt w innych działach prawa. Jeszcze mniej zmian wprowadzała ustawa z dnia 6 września 2001 roku o chorobach zakaźnych i zakażeniach ${ }^{46}$, a przecież zarówno ona, jak i U.z.z.z. przewidywały rozbudowaną siatkę pojęciową. Obu zmianom nie towarzyszyła rewizja art. 161 k.k. Ma to istotną wagę, albowiem k.k. posługuje się sformułowaniami występującymi w aktach normatywnych obowiązujących w dniu jego uchwalenia - w ustawie z dnia 13 listopada 1963 roku o zwalczaniu chorób zakaźnych ${ }^{47}$ (U.z.c.z.) i w dekrecie z dnia 16 kwietnia 1946 roku o zwalczaniu chorób wenerycznych ${ }^{48}$. Artykuł 1 ust. 5 pkt 1 U.z.c.z. „osobę dotkniętą chorobą zakaźną” kazał określać ustawowym mianem „,chory zakaźnie”. Drugi z tych aktów definiował pojęcie „choroby weneryczne”. Na szczególną uwagę zasługuje zaniechanie zastąpienia słów ,zarażenie” słowami „zakażenie” przy zastępowaniu obu tych aktów ustawą z dnia 6 września 2001 roku o chorobach zakaźnych i zakażeniach, wprowadzającą do polskiego prawa definicję legalną zakażenia w jej art. 2 pkt 25. Ów brak koordynacji świadczy o niezależności siatek pojęciowych k.k. i U.z.z.z.

Po trzecie, niezależnie od $\S 148$ ZTP funkcjonuje alternatywne brzmienie skodyfikowanej tam reguły. W miejsce ,dziedziny spraw” pojawia się ,gałąź prawa”: „definicja z podstawowej dla danej gałęzi prawa ustawy (np. z kodeksu) ma zastosowanie w obrębie całej tej gałęzi"49.

43 T. Chauvin, T. Stawecki, P. Winczorek, op. cit., s. 246-247.

$44 \mathrm{~W}$ przedmiocie terminów faktycznych i prawnych zob. M. Zieliński, op. cit., s. 248-249.

45 T. Chauvin, T. Stawecki, P. Winczorek, op. cit., s. 246-247.

46 Dz.U. z 2003 r. Nr 45, poz. 391, i Nr 199, poz. 1938; Dz.U. z 2004 r. Nr 96, poz. 959; Nr 173, poz. 1808; Nr 210, poz. 2135, i Nr 210, poz. 2135; Dz.U. z 2006 r. Nr 220, poz. 1600.

47 Dz.U. z 1963 r. Nr 50, poz. 279; Dz.U. z 1971 r. Nr 12, poz. 115; Dz.U. z 1974 r. Nr 47, poz. 280; Dz.U. z 1989 r. Nr 35, poz. 192; Dz.U. z 1997 r. Nr 60, poz. 369; Dz.U. z 1998 r. Nr 106, poz. 668; Dz.U. z 2000 r. Nr 12, poz. 136; Nr 120, poz. 1268; Dz.U. z 2001 r. Nr 63, poz. 634.

48 Tekst jedn. Dz.U. z 1949 r. Nr 51, poz. 394; Dz.U. z 1975 r. Nr 17, poz. 94; Dz.U. z 2000 r. Nr 120, poz. 1268.

49 Por. S. Lewandowski et al., op. cit., s. 73. 
U.z.z.z. ma podstawowe znaczenie jedynie wśród przepisów o zapobieganiu i zwalczaniu chorób zakaźnych. Uznanie ich za gałąź prawa ${ }^{50}$ budzi wątpliwości. Niezależnie od tego art. 161 k.k. nie mieściłby się w ramach takiej gałęzi. Przeważa jego więź z prawem karnym.

Po czwarte, niektóre pojęcia w k.k. są wykładane w sposób autonomiczny w stosunku do innych dziedzin prawa. Przykładem jest utrwalona w orzecznictwie wykładnia zwrotu „cudzego” w art. 193 k.k., abstrahująca od prawa własności 51 . Praktyka wykładni kodeksowych przepisów karnych nie stoi na przeszkodzie interpretowaniu art. 161 k.k. w oderwaniu od unormowań przeciwepidemicznych.

Po piąte, autorzy powołujący się na definicje legalne z U.z.z.z. na ogół nie stwierdzają stanowczo ich obowiązywania także przy interpretacji art. 161 k.k. ${ }^{52}$ Tylko czasami opisują odgrywaną przez nie rolę. Wspominają, że ustawa karna pośrednio się do nich odwołuje ${ }^{53}$. Stwierdzając, że czerpanie znaczeń z U.z.z.z. to zabieg wykładni systemowej (argumentum a coherentia) ${ }^{54}$, przeczą mocy obowiązującej definicji z jej słowniczka ustawowego na gruncie k.k. ${ }^{55}$

\section{Weryfikacja możliwości zastosowania dyrektywy języka specjalistycznego}

Odrzuciwszy stosowanie dyrektywy języka prawnego do interpretacji jakiegokolwiek wyrażenia, należy rozważyć skorzystanie z dyrektywy języka specjalistycznego, przede wszystkim w stosunku do zwrotów: „zarażenie” w złożeniach „zarażenie wirusem” i ,zarażenie chorobą”, „HIV” czy „choroba” w złożeniach „dotknięty chorobą”, „choroba weneryczna”, „choroba zakaźna”, „ciężka choroba”, „choroba nieuleczalna” i ,choroba realnie zagrażająca życiu”. Nazwa „HIV” ma z pewnością identyczne znaczenie w języku medycyny i w języku ogólnym. Pozostałe przypadki są mniej oczywiste. Można podzielić je na semantycznie związane przede wszystkim z ,zarażeniem” oraz z ,chorobą”.

50 T. Chauvin, T. Stawecki, P. Winczorek, op. cit., s. 153-157.

51 Zob. postanowienie Sądu Najwyższego z 21 lipca 2011 r., sygn. akt I KZP 5/11, Legalis; i wyrok Sądu Najwyższego z 3 lutego 2016 roku, sygn. akt III KK 347/15, Legalis.

52 M. Budyn-Kulik, op. cit., LEX, teza 4; V. Konarska-Wrzosek, Art. 161 Narażenie na zarażenie, [w:] Kodeks karny. Komentarz, red. V. Konarska-Wrzosek, Warszawa 2018, LEX, teza 4; B. Michalski, op. cit., s. 320-326; M. Bartnik, op. cit., s. 8-10; R. Kubiak, op. cit., s. 119, 122.

${ }^{53}$ R. Kokot, op. cit., Legalis, teza 20.

54 T. Chauvin, T. Stawecki, P. Winczorek, op. cit., s. 248. Przy założeniu, że argumentum a coherentia to wskazówka wzbraniająca interpretacji prowadzącej do sprzeczności z innymi przepisami, należałoby odnotować, że prowadzenie wykładni znamion narażenia na zarażenie w oderwaniu od U.z.z.z. nie prowadziłoby do sprzeczności. Dlatego też odwoływanie się do U.z.z.z. nawet w ramach wykładni systemowej jest zbędne.

55 R. Kubiak, op. cit., s. 122. W zakresie „spójności systemu prawnego” zbliżona myśl uobecnia się w R. Kokot, op. cit., Legalis, teza 20. 
Stownik języka polskiego pod redakcją Mieczysława Szymczaka ${ }^{56}$ podaje następujące znaczenie czasownika „zarazić”: „przyczynić się do przeniesienia zarazka na zdrowy organizm, wywołać chorobę zakaźną”. Słowa „zakazić” i „,zakażać” znaczą według niego tyle, co: „spowodować dostanie się drobnoustrojów chorobotwórczych do organizmu, zainfekować, zarazić" ${ }^{57}$. Następnie podaje dwa znaczenia słowa „zakażenie”:

1. rzeczownik od zakazić;

2. proces chorobowy powstały w organizmie, wywołany przez bakterie chorobotwórcze, infekcja ${ }^{58}$.

Maty stownik języka polskiego pod redakcją Haliny Auderskiej, Zofii Łempickiej i Stanisława Skorupki oraz Wielki słownik języka polskiego pod redakcją Elżbiety Sobol ujmują sens słowa „zarazić” w taki sam sposób ${ }^{59}$. W pozostałym zakresie ujawniają się różnice. Według obu słowników „zakazić” czy „zakażać” to tyle co „spowodować dostanie się drobnoustrojów chorobotwórczych do organizmu, do jakiegoś organu, rany itp." ${ }^{\circ 0}$, a „zakażanie” to:

1. rzeczownik od czasownika zakazić;

2. dostanie się drobnoustrojów chorobotwórczych do organizmu, infekcja ${ }^{61}$.

Zaprezentowany przegląd słownictwa języka literackiego prowadzi do dwóch konkluzji:

1. „zakazić” i „zarazić” to wyrazy bliskoznaczne, które w pewnych kontekstach mogą być używane zamiennie; różnice polegają na tym, że „zarażenie” w większym stopniu odnosi się do wywoływania choroby, a czasownik „zakazić” konotuje wnikanie do wnętrza organizmu; uwagi te odnoszą się również do nazw „zarażenie" i ,zakażenie” w ich czynnościowych znaczeniach;

2. „zakażenie” w swym drugim znaczeniu denotuje aktywność drobnoustrojów wnikających do żywych tkanek organizmu i towarzyszący mu proces chorobowy, czyli infekcję.

Na podstawie tych ustaleń możliwe jest sprawdzenie, czy omówione wyrażenia mają znaczenia specjalistyczne, odbiegające od potocznych. W razie potwierdzenia się tej hipotezy znaczenia tych terminów należałoby czerpać ze słownictwa specjalistycznego.

Poczynając od źródła najbardziej ogólnego, należy odnotować, że Encyklopedia powszechna $P W N$ nie zawiera hasła „zarażenie”. Uwzględnia natomiast „zakażenie". Jest to:

56 Słownik języka polskiego, t. 3, red. M. Szymczak, Warszawa 1978, s. 951.

57 Ibidem, s. 913.

58 Ibidem.

59 Maty słownik języka polskiego, red. H. Auderska, Z. Łempicka, S. Skorupka, Warszawa 1969, s. 980; Wielki słownik języka polskiego, red. E. Sobol, Warszawa 2006, s. 1241.

${ }^{60}$ Maty stownik..., s. 967; Wielki stownik..., s. 1222.

${ }^{61}$ Maty stownik..., s. 967; Wielki stownik..., s. 1222. 
infekcja; wtargnięcie do ustroju i rozwój w nim zarazków: bakterii, wirusów, grzybów pasożytniczych; wtargnięcie pasożytów zwierzęcych nazywa się zarażeniem lub inwazją; do zakażenia dochodzi przez drogi oddechowe (zakażenie kropelkowe), drogi pokarmowe (zakażona woda, produkty spożywcze), przez wszczepienie zarazków podczas ukłucia owadów lub pajęczaków, przez kontakt płciowy (choroby weneryczne), przez skórę (głównie uszkodzona) [... $]^{62}$.

Mała encyklopedia medycyny pod redakcją Tadeusza Rożniatowskiego też pomija pojęcie zarażenia. O zakażeniu mówi:

Zakażenie, infekcja, wtargnięcie drobnoustrojów chorobotwórczych do organizmu. Miejsce wtargnięcia drobnoustrojów nazywa się wrotami zakażenia. [...] Następstwa zakażenia mogą być różne. Niekiedy siły obronne ustroju doprowadzają do zniszczenia zarazków już we wrotach zakażenia, bezpośrednio po ich wtargnięciu. Jeśli to nie nastąpiło, drobnoustroje mogą się rozmnażać we wrotach zakażenia (na przykład w migdałkach lub w ranie) ${ }^{63}$.

Literatura medyczna nie stosuje nazw „zakażenie” i ,zarażenie” zamiennie. Terminu „zarażenie” używa się w odniesieniu do pasożytów. W podręczniku Mikrobiologia lekarska pod redakcją Piotra B. Heczki, Agaty Pietrzyk i Marty Wróblewskiej w rozdziałach poświęconych parazytologii pojawiają się sformułowania: „zarażenie pasożytami”64, „ze strony zarażonego człowieka niezbędna jest neutralizacja obecności pasożyta" ${ }^{65}$, ,zarażonego żywiciela" ${ }^{66}$, „po zarażeniu włośniem krętym" ${ }^{\circ 7}$. Z kolei wtargnięcie do organizmu bakterii, wirusów czy grzybów jest określane mianem „zakażenia”. „Zarażenie” konotuje patogenezę inną niż ,zakażenie"68. Potwierdzają to słowa przytoczonego opracowania:

Epidemiologia inwazji pasożytniczych ma pewne cechy, które odróżniają je od epidemiologii chorób zakaźnych. [...] Znajduje to swój wyraz chociażby w mianownictwie. W przypadku wirusów i bakterii mówi się o zakażeniu, a w przypadku pasożytów zwierzęcych o zarażeniu ${ }^{69}$.

Podręcznik Choroby zakaźne i pasożytnicze pod redakcją naukową Zdzisława Dziubka również używa słów „zarazić” i „,zarażenie” w odniesieniu do pasożytów zwierzęcych. Przykładowo mowa jest o „bakteryjnych zakażeniach wewnątrzkomórkowych i zarażeniach pasożytami" ${ }^{70}$. W tekście spotyka się jednak przypadki użycia słowa „zarazić” w znaczeniu odpowiadającym bardziej językowi potoczne-

62 Encyklopedia powszechna PWN, t. 4, Warszawa 1973, s. 977.

63 Mała encyklopedia medycyny, t. 3, red. T. Rożniatowski, Warszawa 1989, s. 1393-1394.

64 Z. Pawłowski, Parazytologia ogólna, [w:] Mikrobiologia lekarska, red. P.B. Heczko, A. Pietrzyk, M. Wróblewska, Warszawa 2014, s. 484.

65 Ibidem, s. 485.

${ }^{66}$ A. Pietrzyk, Trypanosoma spp., [w:] Mikrobiologia lekarska, red. P.B. Heczko, A. Pietrzyk, M. Wróblewska, s. 503.

67 Z. Pawłowski, op. cit., s. 480.

68 R. Kokot, op. cit., Legalis, teza 20.

69 Z. Pawłowski, op. cit., s. 488.

70 J. Ślusarczyk, Rola uktadu odpornościowego w zakażeniach i odporności poszczepiennej, [w:] Choroby zakaźne i pasożytnicze, red. Z. Dziubek, Warszawa 2012, s. 26. 
mu. Mowa jest o zarażeniu chorobą, nie zaś drobnoustrojem ${ }^{71}$. Autor opisywał co prawda chorobę pasożytniczą (zimnicę), niemniej świadczy to o pewnej swobodzie. Czasownik ,,zarazić” został użyty także do opisu przeniesienia choroby bądź zarazków o innej patogenezie. Rzuca się w oczy następująca wypowiedź o płonicy, chorobie wywoływanej przez bakterie — szczepy paciorkowców grupy A:

Źródłem zakażenia jest człowiek chory na płonicę, na paciorkowcowe zapalenie gardła, a także zdrowy nosiciel drobnoustroju. Zarazić się można również pośrednio, przez odzież i sprzęty [... $]^{72}$.

Czytelnik nie może mieć pewności czy określenia ,zakażenia” i ,zarazić się” oznaczają tu tożsamy proces. Uwagę zwraca jednak odstępstwo od dystynkcji tak jasno wyłożonej we wcześniej cytowanym podręczniku. Za pomocą czasownika „zarazić się” opisano chorobę inną niż pasożytnicza. Podobne użycie słowa ,zarażenie" można spotkać w rozdziale zatytułowanym Zakażenie Helicobacter pylori:

Zakażenie [...] szerzy się przede wszystkim wskutek bliskich kontaktów międzyludzkich. W rejonach o niskiej higienie zarażenie odbywa się na drodze fekalno-oralnej ${ }^{73}$.

O ,zarażeniu” chorobami zakaźnymi (nie pasożytniczymi) lub ,zarażeniu” drobnoustrojami je wywołującymi jest mowa również w innych ustępach publikacji ${ }^{74}$.

Ewelina Król stwierdziła, że o „zarażeniu” mówi się zwykle, opisując przeniesienie czynnika zaraźliwego na człowieka. Zarazić można się na przykład drogą kropelkową, gdy ktoś kichnie. Wtedy w organizmie dochodzi do zainfekowania, czyli zakażenia $^{75}$. W takim znaczeniu o zarażeniu traktował podręcznik Choroby zakaźne i pasożytnicze $e^{76}$.

Analiza źródeł nasuwa następujące wnioski. W profesjolekcie medycznym występuje ostre rozgraniczenie między zakresami nazw „zarażenie” i „zakażenie”, nawiązujące do patogenezy wtargnięcia mikroorganizmów do ustroju i spowodowanego przez to stanu. Nie jest ono zawsze przestrzegane. Autorom publikacji poświęconych chorobom zakaźnym zdarza się używać słów z rodziny czasownika „zarazić” na określenie stanu spowodowanego przez drobnoustroje inne niż pasożyty zwierzęce. Równolegle funkcjonuje drugie rozróżnienie. Polega ono na przypisywaniu nazwie ,zarażenie” konotacji obejmującej przeniesienie bakterii, wirusa, grzyba czy pasożyta zwierzęcego do innego ustroju. Nazwa ta ukazuje relacje zachodzące między ustrojem jako całością a bliżej nieokreślonym czyn-

71 Z. Dziubek, Etiopatogeneza chorób zakaźnych, [w:] Choroby zakaźne..., s. 31.

72 Z. Dziubek, Zakażenia wywołane przez bakterie Gram-dodatnie, [w:] Choroby zakaźne..., s. 99.

73 Z. Dziubek, Zakażenie Helicobacter pylori, [w:] Choroby zakaźne..., s. 171.

74 Z. Dziubek, Krętkowice, [w:] Choroby zakaźne..., s. 210; P. Kajfasz, Różyczka, [w:] Choroby zakaźne..., s. 281; A. Kotłowski, Denga i goraczka krwotoczna denga, [w:] Choroby zakaźne..., s. 303.

75 D. Mielcarek, Koronawirus. Czym różni się zarażenie od zakażenia?, https://portal.abczdrowie.pl/koronawirus-czym-rozni-sie-zarazenie-od-zakazenia (dostęp: 21.12.2020).

76 Por. przyp. 72, 75, 76. 
nikiem zawierającym patogenetyczne mikroorganizmy. Nie opisuje aktywności samych drobnoustrojów. Natomiast „zakażenie” znaczy w świetle tego rozróżnienia tyle, co „wtargnięcie drobnoustrojów do ustroju i towarzysząca temu reakcja tegoż organizmu". Termin ten w większym stopniu konotuje aktywność zarazków niż ich nośników. Tak rozumiane zakażenie jest następstwem zarażenia. Nie ulega wątpliwości, że pierwsze z omówionych rozróżnień nie jest rozpoznawalne dla użytkowników języka potocznego spoza fachowych kręgów medycznych. Druga z nich nawiązuje zaś do ogólnego pojmowania zakażenia jako procesu patologicznego. W profesjolekcie medycznym współistnieją zatem dwa znaczenia nazwy „zarażenie”.

W art. 161 k.k. ustawodawca z pewnością nie traktuje „zarażenia” jako procesu wniknięcia jedynie pasożyta zwierzęcego do ludzkiego ciała. Sformułowanie „zarażenie wirusem HIV” byłoby wówczas wewnętrznie sprzeczne. Użycie owego zwrotu w art. $161 \S 1$ k.k. jest zarazem zgodne z pojmowaniem zarażenia jako przeniesienie czynnika chorobotwórczego na inną osobę. Ta zgodność nie zachodzi w art. 161 § 2 k.k., w którym pojawia się zwrot „zarażenie chorobą”. Jeżeli choroba jest reakcją ustroju na czynnik chorobotwórczy ${ }^{77}$, to chorobą nie można się ani „zarazić”, ani „zakazić”, przynajmniej w specjalistycznym sensie obu czasowników. Wskazana tu nieadekwatność oznacza, że k.k. nie posługuje się językiem specjalistycznym. Odwoływanie się do języka medycyny nie jest zasadne. Wykładnia poszczególnych zwrotów w art. $161 \S 2$ k.k. i jak się wydaje także art. $161 \S 1$ k.k. musi opierać się na dyrektywie języka potocznego (ogólnego).

Przechodząc do znaczenia nazwy „choroba” i nazw złożonych, których członem jest słowo „choroba”, należy najpierw zrekonstruować ogólny sens tego słowa. Słownik języka polskiego pod redakcją Mieczysława Szymczaka zawiera następującą definicję: ,,proces patologiczny objawiający się zaburzeniem czynności organizmu"78. Objaśnienia o takim samym brzmieniu zawierają Mały stownik języka polskiego ${ }^{79}$ oraz Wielki słownik języka polskiego ${ }^{80}$.

Znaczenie przymiotnika „zakaźny” dwa ostatnie słowniki ujmują w słowa:

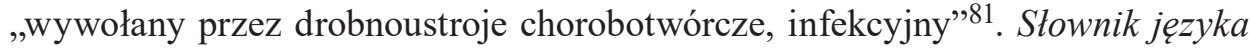
polskiego pod redakcją Mieczysława Szymczaka objaśnia to samo hasło w odmienny sposób: „wywołany przez zakażenie; powodujący zakażenie; zaraźliwy, infekcyjny" "2. Wszystkie trzy słowniki egzemplifikują usus tego przymiotnika podając kolokację „choroba zakaźna”.

Rozumienie pojęcia choroby w języku specjalistycznym jest bardziej rozbudowane. Encyklopedia powszechna PWN definiuje to zjawisko następująco:

77 Encyklopedia powszechna PWN, t. 1, Warszawa 1973, s. 458.

78 Stownikjęzyka..., t. 1, s. 273-274.

79 Maty stownik..., s. 77.

80 Wielki stownik..., s. 88.

${ }^{81}$ Ibidem, s. 1222; Maty stownik..., s. 967.

82 Stownikjęzyka..., t. 3, s. 913. 
reakcja dynamiczna ustroju na działanie czynnika chorobotwórczego; wyraża się zaburzeniami we współdziałaniu narządów i tkanek. [...] Niekiedy choroba przebiega bezobjawowo (choroba utajona $^{83}$.

Natomiast hasłu ,zakaźne choroby” towarzyszy następujące objaśnienie: „choroby infekcyjne, schorzenia ludzi i zwierząt wywołane zakażeniem [...]"84. Mała encyklopedia medycyny pod redakcją Tadeusza Rożniatowskiego objaśnia oba pojęcia takimi samymi słowami ${ }^{85}$. W dalszej części objaśnienia hasła „zakażenie” można przeczytać zdania:

Gdy siły obronne ustroju nie są wystarczające do ograniczenia rozwoju drobnoustrojów we wrotach zakażenia, powstaje choroba zakaźna. Jest to stan, w którym wtargnięcie do ustroju drobnoustrojów chorobotwórczych doprowadziło do ich rozplemu, z wywołaniem w zakażonym organizmie charakterystycznego zespołu objawów miejscowych i ogólnych ${ }^{86}$.

Nazwa „choroba zakaźna” jest często zestawiana z nazwą „choroba pasożytnicza"87. Ich zakresy pozostają w relacji przeciwieństwa. To nie koreluje z rozumieniem nazwy „choroba zakaźna” w języku potocznym, gdzie jej pierwszorzędną cechą semantyczną jest patogeneza (ogólnie) mikrobiologiczna, w tym pasożytnicza.

Porównanie znaczeń przyjętych w języku medycyny i w ogólnym języku literackim skłania do konkluzji, iż sama nazwa „choroba” ma szerszą denotację w języku medycyny. Nie każda ,reakcja dynamiczna ustroju na czynnik chorobotwórczy” stanowi ,proces patologiczny”. Praktyczne znaczenie tego rozdźwięku jest znikome. W obu odmianach języka nazwa „choroba” jest kojarzona z objawami, choć może opisywać także choroby utajone (o przebiegu bezobjawowym) ${ }^{88}$. Co więcej, nazwa „,choroba”, tak jak wszystkie słowa użyte w art. 161 k.k., jest powszechnie używana w codziennej praktyce językowej, a potoczny zwrot „,zarażenie chorobą” stanowi użycie słowa „choroba” w sposób niezgodny z medycznym znaczeniem słowa ,zarażenie”.

Brak wyraźnego specjalistycznego znaczenia słowa „choroba” jest równoznaczny z brakiem podstaw do odstąpienia od stosowania dyrektywy języka potocznego. Podstawy takie zachodzą w stosunku do kolokacji „choroba zakaźna”. Jej znaczenie w profesjolekcie medycznym odbiega od potocznego.

Jednakże wyłączenie chorób pasożytniczych z zakresu znamienia „choroba zakaźna" prowadziłoby do naruszenia zasady równości wobec prawa. Liczne choroby pasożytnicze są letalne. Mogą być przy tym przenoszone w wyniku działań

83 Encyklopedia powszechna PWN, t. 1, s. 458.

${ }^{84}$ Ibidem, t. 4, s. 755.

85 Mała encyklopedia..., t. 1, s. 157 i 161.

86 Ibidem, t. 3, s. 1393-1394.

${ }^{87}$ Zob. przypis 70. Choroby pasożytnicze są też zwane inwazyjnymi. Zob. Mała encyklopedia..., t. 1, s. 159 .

88 Ibidem, s. 157. 
ludzi ${ }^{89}$. Przykładowo, zarodziec malaryczny wywołujący malarię (zimnicę) może być przeniesiony między organizmami ludzkimi przy transfuzji krwi ${ }^{90}$ albo niezgodnym z prawidłami aseptyki używaniu igieł strzykawek.

Skorzystanie ze znaczenia specjalistycznego byłoby poprawne, ale skutki tego posunięcia zostałyby zniweczone na kolejnym etapie wykładni. Systemowe dyrektywy wykładni wymagają odrzucenia takich znaczeń interpretowanego zwrotu, które prowadzą do konfliktu z normami hierarchicznie wyższymi ${ }^{91}$. Aby zachować zgodność art. 161 § 2-3 k.k. z konstytucyjną zasadą równości wobec prawa, zakres nazwy „choroba zakaźna” musi rozciągać się na choroby pasożytnicze.

\section{Wnioski}

Wykładnia językowa znamion czynów stypizowanych w art. 161 k.k. powinna być dokonywana w całości na podstawie dyrektywy języka potocznego. Dyrektywę języka prawnego należy odrzucić, jako że nie ma terminów prawnych w art. 161 k.k. Brak podstawowego znaczenia U.z.z.z. dla epidemiologii czy dla prawa karnego oznacza, że nie ma podstaw do czerpania znaczenia zwrotów „HIV” i „choroba zakaźna” ze słowniczka ustawowego U.z.z.z., który zresztą nie ustala specyficznych dla nich znaczeń. Również dyrektywa języka specjalistycznego nie zasługuje na uwzględnienie. Niektóre zwroty zostały użyte w art. 161 k.k. w sposób niezgodny z prawidłami terminologii medycznej. Znaczenia innych słów nie odbiegają w profesjolekcie medycznym od przyjętych w słowniku języka ogólnego. Wyjątek tworzy termin „choroba zakaźna”. Jego rozumienie należałoby zaczerpnąć z języka medycyny. Jednakże wykładnia systemowa przesądza o obowiązywaniu znaczenia zbieżnego z funkcjonującym w języku potocznym, obejmującym także choroby pasożytnicze.

De lege ferenda należałoby postulować nowelizację art. $161 \S 1-2$ k.k. Przepisy winny być zredagowane w zgodzie z prawidłami języka medycyny. Pozwoliłoby to na uwzględnienie dyrektywy języka specjalistycznego przy wykładni typizacji narażenia na zakażenie (a nie „zarażenie”).

\section{Bibliografia}

Banasik K., Przestępstwo narażenia na zarażenie wirusem HIV (art. 161 \& 1 k.k.), „Prokuratura i Prawo" 2009, nr 6, s. 53-61.

Bartnik M., Odpowiedzialność karna za narażenie na zarażenie HIV i AIDS, „Studia Prawnicze KUL”2017, nr 3 (71), s. 7-15, https://www.kul.pl/files/1702/sp_kul_3_2017_-_pojedynczo/01_ bartnik.pdf.

89 J. Morozińska-Gogol, Parazytologia medyczna, Warszawa 2016, s. 8.

90 Ibidem, s. 87.

91 M. Zieliński, op. cit., s. 297-298. 
Budyn-Kulik M., Art. 161. Narażenie człowieka na zarażenie, [w:] M. Budyn-Kulik, P. Kozłowska-Kalisz, M. Kulik, M. Mozgawa, Kodeks karny. Komentarz aktualizowany, Warszawa 2020, LEX.

Chauvin T., Stawecki T., Winczorek P., Wstęp do prawoznawstwa, Warszawa 2016.

Derlatka M., Zasadność kryminalizacji narażenia na zarażenie wirusem HIV, „Palestra” 2013, z. 7-8, s. 164-167.

Dziubek Z., Etiopatogeneza chorób zakaźnych, [w:] Choroby zakaźne i pasożytnicze, red. Z. Dziubek, Warszawa 2012.

Dziubek Z., Krętkowice, [w:] Choroby zakaźne i pasożytnicze, red. Z. Dziubek, Warszawa 2012.

Dziubek Z., Zakażenia wywołane przez bakterie Gram-dodatnie, [w:] Choroby zakaźne i pasożytnicze, red. Z. Dziubek, Warszawa 2012.

Dziubek Z., Zakażenie Helicobacter pylori, [w:] Choroby zakaźne i pasożytnicze, red. Z. Dziubek, Warszawa 2012.

Encyklopedia powszechna PWN, t. 1 i 4, Warszawa 1973.

Kajfasz P., Różyczka, [w:] Choroby zakaźne i pasożytnicze, red. Z. Dziubek, Warszawa 2012.

Kaleta K.J., Kotowski A., Podstawy prawoznawstwa, Warszawa 2016.

Kamieński G., Odpowiedzialność cywilna i karna za zarażenie koronawirusem, Warszawa 2020, LEX.

Karge H., Palka P., Przestępstwo narażenia na zakażenie choroba zakaźna (art. $161 \xi 2$ k.k.) przeglad problemów, „Studia Prawnoustrojowe” 2018, nr 39, s. 65-81, https://wpia.uwm.edu.pl/ czasopisma/sites/default/files/uploads/Studia_Prawno_Ustrojowe/2018/39/65-82.pdf.

Karnat J., Art. 161. [Narażenie na zarażenie], [w:] M. Banaś-Grabek, B. Gadecki, J. Karnat, A. Łyżwa, R. Łyżwa, Kodeks karny. Część szczególna. Art. 148-251. Komentarz, Warszawa 2020, Legalis.

Kokot R., Art. 161. [Narażenie na zarażenie], [w:] Kodeks karny. Komentarz, red. R.A. Stefański, Warszawa 2020, Legalis.

Konarska-Wrzosek V., Art. 161. [Narażenie na zarażenie], [w:] Kodeks karny. Komentarz, red. V. Konarska-Wrzosek, Warszawa 2018, LEX.

Konarska-Wrzosek V., Marek A., Prawo karne, Warszawa 2019.

Kotłowski A., Denga i goraczka krwotoczna denga, [w:] Choroby zakaźne i pasożytnicze, red. Z. Dziubek, Warszawa 2012.

Krej N., COVID-19. Ustawy antykryzysowe. Zbiór przepisów z omówieniem, Warszawa 2020, Legalis.

Kubiak R., Odpowiedzialność karna za narażenie na zakażenie wirusem SARS-CoV-2, „Palestra” 2020, nr 6, s. 113-136.

Lewandowski S., Machińska H., Malinowski A., Petzel J., Logika dla prawników, Warszawa 2013. Mała encyklopedia medycyny, t. 1 i 3, red. T. Rożniatowski, Warszawa 1989.

Mały słownik języka polskiego, red. H. Auderska, Z. Łempicka, S. Skorupka, Warszawa 1969.

Marek A., Kodeks karny. Komentarz, Warszawa 2010, LEX.

Michalski B., Szczególne wypadki odpowiedzialności karnej związane z narażeniem człowieka na bezpośrednie niebezpieczeństwo utraty życia albo ciężkiego uszczerbku na zdrowiu, [w:] System Prawa Karnego, t. 10. Przestępstwa przeciwko dobrom indywidualnym, red. J. Warylewski, Warszawa 2016.

Mielcarek D., Koronawirus. Czym różni się zarażenie od zakażenia?, https://portal.abczdrowie.pl/ koronawirus-czym-rozni-sie-zarazenie-od-zakazenia.

Morozińska-Gogol J., Parazytologia medyczna, Warszawa 2016.

Pawłowski Z., Parazytologia ogólna, [w:] Mikrobiologia lekarska, red. P.B. Heczko, A. Pietrzyk, M. Wróblewska, Warszawa 2014.

Pietrzyk A., Trypanosoma spp., [w:] Mikrobiologia lekarska, red. P.B. Heczko, A. Pietrzyk, M. Wróblewska, Warszawa 2014.

Studenckie Prace Prawnicze, Administratywistyczne i Ekonomiczne 37, 2021

(C) for this edition by CNS 
Piwowarska K., Piwowarski T., Metodyka postępowania w sprawach z zakresu prawa pracy na podstawie Regulacji COVID-19, Warszawa 2020, Legalis.

Stownik języka polskiego, t. 1 i 3, red. M. Szymczak, Warszawa 1978.

Ślusarczyk J., Rola układu odpornościowego w zakażeniach i odporności poszczepiennej, [w:] Choroby zakaźne i pasożytnicze, red. Z. Dziubek, Warszawa 2012.

Wielki słownik języka polskiego, red. E. Sobol, Warszawa 2006.

Wyrembak J., Zasadnicza wyktadnia znamion przestęstw. Pozycja metody językowej oraz rezultatów jej użycia, Warszawa 2009, LEX.

Ziembiński Z., Logika praktyczna, Warszawa 2012.

Zieliński M., Wykładnia prawa. Zasady — reguły - wskazówki, Warszawa 2017.

\section{Orzecznictwo}

Postanowienie Sądu Najwyższego z dnia 21 lipca 2011 roku, sygn. akt I KZP 5/11, Legalis. Wyrok Sądu Najwyższego z dnia 3 lutego 2016 roku, sygn. akt III k.k. 347/15, Legalis. 